\title{
¿Por qué surgió Gaceta Médica de México?
}

\author{
Martha Eugenia Rodríguez-Pérez \\ Academia Nacional de Medicina, Gaceta Médica de México, Ciudad de México, México
}

En la actualidad, en México circula un sinnúmero de publicaciones periódicas especializadas en medicina, propicias y oportunas, como diría el doctor Gonzalo Castañeda "para comunicar breve y prontamente la adquisición de ayer..., la idea que acaba de surgir de la mente del pensador", pero la más antigua es Gaceta Médica de México, que data del 15 de septiembre de 1864. Fue editada por los socios de la Sección de Ciencias Médicas de la Comisión Científica, Literaria y Artística de México, creada en 1864 a instancia de los integrantes del ejército expedicionario francés.

La asociación, creada el 30 de abril de 1864 y denominada inicialmente como Sección de Ciencias Médicas, se transformó en 1865 en Sociedad Médica de México y en 1873 en Academia Nacional de Medicina, conservando la Gaceta Médica de México como órgano de difusión. La Sección de Ciencias Médicas se integró por 22 especialistas de la salud, 10 mexicanos y 10 franceses, un alemán y un italiano. Su presidente fue el doctor Carlos Alberto Ehrmann y los vicepresidentes, primero y segundo, respectivamente, Miguel Francisco Jiménez y Julio Clement, quienes, en colaboración con los demás socios, se percataron de la necesidad de preservar los trabajos presentados en la asociación. La mejor manera de difundirlos fue precisamente por medio del periodismo.

Tras cuatro meses de reunir el material presentado en las sesiones de los miércoles, se publicó el primer número de Gaceta Médica de México, en su documento inicial titulado "Prospecto" (Gac Med Mex. 1864;1(I):1), se lee: "La acogida favorable que constantemente se ha dado en nuestro país a los esfuerzos repetidos hasta hoy para popularizar las ciencias, y en especial la Medicina, por medio de publicaciones periódicas, ha probado suficientemente la necesidad de tales publicaciones". Los doctores Ehrmann y Jiménez, los autores, dejaban ver que la
Academia requería un periódico debido al trabajo que estaba llevando a cabo, por "la actividad que se nota entre sus miembros... la regularidad de sus trabajos y... el entusiasmo a que da origen la amenidad de sus reuniones", que sobrepasaban el horario establecido.

Para facilitar la suscripción al periódico se designaron dos espacios: la alacena de don Antonio de la Torre (que actualmente equivaldría a un puesto de periódicos) y el domicilio particular del editor, el doctor Luis Hidalgo y Carpio, especialista en medicina legal y autor de la doctrina médica contenida en el Código Penal Mexicano que promulgaría el presidente Benito Juárez en 1871.

La Gaceta se "apropió" de conocimientos, ya que en sus páginas integró información proveniente de publicaciones extranjeras, además de "cuantas comunicaciones de interés quieran dirigirle las personas inteligentes". Se esperaba impulsar el espíritu de confraternidad, "que en todas partes distingue a la porción más escogida de los médicos". El rotativo reflejaría el movimiento ideológico científico de las áreas de la salud; en él regiría la misma libertad que caracterizaba a las discusiones académicas y se responsabilizaba a cada autor de los conceptos que expresara. Para que los lectores alcanzaran una total comprensión, se pensó en una publicación bilingüe, lo que se cumplió sólo en el primer tomo, que incluyó artículos en español y francés; para los siguientes volúmenes se recurrió al equipo de traductores.

Los afiliados a la Academia de Medicina acudían a las sesiones para intercambiar conocimientos sobre la epidemiología nacional, conocer la etiología de las enfermedades que reinaban en México y buscar soluciones. Estas inquietudes se plasmaron en la Gaceta, donde la comunidad médica mexicana dejaba por escrito las discusiones y trabajos presentados en la Academia.
Fecha de recepción: 02-07-2018

Fecha de aceptación: 10-07-2018

DOI://dx.doi.org/10.24875/GMM.18004493
Gac Med Mex. 2018;154:425-426

Disponible en PubMed

www.gacetamedicademexico.com 
Hidalgo y Carpio y los siguientes editores, como Agustín Andrade, José María Reyes y Domingo Orvañanos, señalaron que deseaban que Gaceta Médica de México fuera conocida en el "mundo científico", de ahí su interés por traspasar las fronteras mexicanas mediante el canje de publicaciones. En 1886, el tiraje era de 350 ejemplares, que se distribuían a los socios, 35 sociedades científicas nacionales y a 75 sociedades extranjeras. Para lograr una buena administración, el editor recibía un sueldo de 480 pesos anuales.

Entre los temas que se abordaron en los diversos volúmenes de la Gaceta del siglo XIX figuran los descubrimientos médicos y las nuevas teorías (como la celular), los avances quirúrgicos, la anestesia, la antisepsia y la asepsia, con los que la cirugía se tornaba muy atractiva; el nacimiento de la bacteriología, la discusión sobre la vacuna contra la viruela, la incorporación de la tecnología a la medicina, el surgimiento de las especialidades médicas en México a partir de 1888 (oftalmología, ginecología, bacteriología y enfermedades mentales) y las enfermedades recurrentes.

En 1877, la Gaceta anunciaba que el tifo alarmaba a la población debido a que estaba estacionado en la capital y se iba extendiendo por el territorio nacional. Años más tarde, en 1915, entre otros medios, Gaceta Médica de México difundió las declaraciones del doctor José María Rodríguez, presidente del Consejo Superior de Salubridad, respecto a la identificación del piojo como vector de transmisión de la enfermedad.

Fue tal la abundancia de material y temas que resguardaba la Gaceta que, en 1886 Agustín Andrade, miembro fundador de la Academia, manifestaba la necesidad de elaborar un índice de la publicación. Tras un arduo trabajo, en 1888, el editor de la Gaceta, el doctor Manuel S. Soriano, anunciaba la publicación del índice general de los 23 tomos de la Gaceta Médica, por materias y autores; su precio: dos pesos. El catálogo resultó tan útil y novedoso en su momento, que fue exhibido en el estand que instaló México en la Exposición Universal de París en 1889, precisamente cuando se finalizaba la construcción de la Torre Eiffel, que serviría como símbolo principal de la celebración.

El doctor Francisco Fernández del Castillo elaboró el índice de Gaceta Médica de México que abarca de 1836 a 1956, ya que incluye los periódicos de las primeras Academias: Periódico de la Academia de Medicina de Mégico, seis tomos, publicados entre 1836 y 1843, y Periódico de la Academia de Medicina de México, un tomo, y la Unión Médica de México, dos tomos, 1856 a 1858. La relación que cubrió del periodo de 1957 a 1976 fue realizada por Alejandro Somolinos. Está por demás mencionar los beneficios del catálogo, que permite un fácil manejo de la revista, por lo que queda pendiente su actualización.

Cuando llegó el año 1900 y salía de imprenta el tomo 37 de la Gaceta, la Comisión de Publicaciones resolvió terminar la primera época y para el nuevo siglo y año comenzar una segunda serie, según lo exigían los adelantos tipográficos, por lo que los siguientes números mejoraron la presentación que sería en papel couché.

En suma, Gaceta Médica de México, trabajada siempre con gran profesionalismo, es portavoz de la Academia Nacional de Medicina, cuyo fin es transmitir la investigación realizada en materia de salud, la discusión, análisis y reflexión de los postulados de la ciencia, así como el medio de difusión de los documentos de postura, por lo que podríamos decir que sigue vigente la frase del titular de la Academia en 1866, el doctor Miguel Francisco Jiménez:

...nuestro único propósito [al editar la Gaceta] consiste en dejar acumulados, sin confundirse los hechos que han pasado a nuestra vista, para que en días más serenos y por hombres más competentes puedan ser fecundados con positiva ventaja y utilidad para la ciencia...dará, sí, testimonio, en la originalidad de las materias, del amor al estudio y del interés nacional que nos anima...

(Jiménez MF. Sesión de clausura. Gac Med Mex. 1866;2: 385-386). 